\title{
Reading Die Blechtrommel throughout Europe: Introduction
}

\author{
Jos Joosten \& Christoph Parry
}

The death of Günter Grass on 23rd April 2015 occurred while the present book was being prepared for publication. The attention that the Nobel laureate's death received in media around the world once more confirmed his special status as a writer and public figure. Of all the works of Günter Grass the one book that no obituary failed to mention was Die Blechtrommel (The Tin Drum), the novel that instantly made Grass famous in 1959 and, while not to everybody's liking, is generally recognised as a masterpiece. Quite soon after its appearance on the German book market the first translations began to appear and within a few years the novel was raised to something approaching canonical status, not only in the country of its origin. But what does such recognition mean in practice? How does it come about, does it follow similar lines in different parts of Europe and how far is it dependent on the organisation of literary life or, to use Pierre Bourdieu's term, the literary field in different parts of Europe? In short, is Die Blechtrommel a European novel? These are questions addressed in this collection of articles.

The idea for this study evolved from the work of the SCARAB research project at the Radboud University in Nijmegen and the centre for research into Finnish-German literary and cultural relations at the University of Vaasa. Already working on reviewing practice and literary reception from bilateral perspectives, the need was felt by both teams for a pilot study that would examine the reception of a single well known work across Europe as a whole, in order to locate both common ground and regional peculiarities of the reception process. For such a study to produce viable results the material examined needed to be sufficiently familiar throughout the continent and established over a longer period of time. In view of these criteria Die Blechtrommel was an obvious choice.

Die Blechtrommel is historical in both senses of the word. It is a historical novel in that it deals with events of recent history, but its appearance on the German book market can in hindsight also be considered a historically significant event. The publication of the novel in 1959 has been hailed as marking the return of contemporary German literature to the European literary scene. For almost three decades, since 1933, modern German literature was represented outside the German speaking countries, if at all, by authors like Franz Kafka,

(C) JOS JOOSTEN AND CHRISTOPH PARRY, 2016 | DOI 10.1163/9789004291898_002

This is an open access chapter distributed under the terms of the CC-BY-NC License. 
Thomas Mann, Bertolt Brecht or Stefan Zweig, and works written either before the 1930s or written in exile. Work written inside Germany during the Third Reich and its aftermath tended to be regarded at best as singularly provincial. But with the startling figure of Oskar Matzerath banging his tin drum, contemporary German literature written in Germany itself returned to the world stage.

The year 1959 has often been described as an 'annus mirabilis' of West German literature with the appearance of books like Uwe Johnson's Mutmaßungen über Jakob and Heinrich Böll's Billard um halbzehn in addition to Grass's monumental novel. While the West German literary scene at large benefited from a surge of talent, it was Grass's novel that received the most international attention at the time and it is certainly the one German novel of that year which has passed the test of time both in Germany and elsewhere. Unusually for a first novel, its first publication already met with high expectations due to the advance publicity it had received when Grass read a prizewinning excerpt at the meeting of the Gruppe 47 the previous year. But although media interest was already there, on first appearance the novel was met in Germany with mixed feelings. It was openly rejected by many more conservative critics, ostensibly for its obscenities and hints of blasphemy, but on a deeper level probably also for touching on an issue so sensitive that the critics themselves were hesitant to name it expressly: the collusion of the ordinary German population with the Nazi regime. Not that this issue was completely absent from German literature of the time, but its cautious treatment in novels like Heinrich Böll's Billard um halbzehn which appeared in the same year as Die Blechtrommel or its more outspoken condemnation in Christian Geißler's Anfrage, published a year later, was generally accompanied by an openly moralising or even didactic tendency that was conspicuously absent from Grass's first novel. Grass leaves the moralising to his readers whom he credits with sufficient maturity to achieve the task without detailed instructions from the author. However, even in Germany itself the negative reviews did as much to promote the work in the long run as the eulogies of more progressive critics. The hint of scandal transformed the publication of the novel into a literary event, which was registered well beyond the borders of Germany itself.

By the 1970 s the novel was already being mentioned in literary histories as a turning point in post-war German literature. What may initially have been the arguable opinion of some literary historians has since become something like a received truth, which colours the whole reception process of both book and author. Thus in 2009, the fiftieth anniversary of the initial publication of the novel and the occasion of the publication of a new English translation, the online edition of The Guardian published a discussion of the book in its "books 
blog" under the headline "The Tin Drum summarised the 2oth century in three words" stating in the lead sentence "Fifty years on, Günter Grass's seminal work remains the defining novel of the 2oth century, wrenching art and hope from ugliness and horror." This sentence highlights an issue on which the opinions of earlier reviewers of the book were divided: whether or not what Grass had done in his novel could be classified as art. Easily pronounced in 2009, this sentence is in fact more pertinent to the initial impact of the novel on the West German literary scene than the writer in The Guardian may have been aware, since it sums up and passes judgement on a debate that had overshadowed the intellectual atmosphere in Germany throughout the 1950s. Upon the first appearance of Die Blechtrommel in 1959 the moral discussion about whether it was at all possible to wrench "art and hope from ugliness and horror," and indeed, whether the production of art after Auschwitz was even legitimate at all, was still going on. Theodor W. Adorno's famous dictum, that it was barbaric to write poetry after Auschwitz, is often cited in this connection, as is the reception of Paul Celan's famous poem "Todesfuge". ${ }^{2}$ Barbaric or not, Die Blechtrommel certainly demonstrated the unbroken viability of literature after Auschwitz, but qualms about the appropriateness of such an exuberant novel certainly affected the climate of its early critical reception in Germany.

It has been suggested that Die Blechtrommel should not be regarded as a "single masterpiece", but rather that Grass, like Kafka, Proust or Borges, "is the author of a complex narrative system in many ways equivalent to a single book [...] a negative memory of German and Central European twentieth century history."3 In retrospect and in view of the many continuities in Grass's writing this view is legitimate, but in practice this first novel has indeed been treated by critics as the single real masterpiece of the author and has become the yardstick against which all Grass's later writing and even his activities as a politically active public figure have been measured. This early work raised expectations that it would be hard for anybody to live up to, even for Günter Grass.

The essays in this book present a mosaic, discussing the reception of Die Blechtrommel in different countries and at the same time highlighting different aspects of the issue of transcultural reception. The overall approach of the

1 Darragh McManus in online edition of The Guardian at <http://www.theguardian.com/books/ booksblog/2009/oct/07/the-tin-drum-gunter-grass $>$. [cited 28.03.2015]

2 Adorno (1998) 30. For discussion of the problematic reception of Celan's "Todesfuge" poem see Packalén (2005) 126-127.

3 Helena Gonçalves da Silva: Peeling the Onion by Günter Grass. From Survivor Memory to Postmemory, and the Issue of a responsible European Culture of Memory. In: Braun/Brunssen (Eds.): Changing the Nation, 156. 
essays, while by no means uniform, can be broadly described as an application of reception studies tempered by Bourdieu's insights into the dependence of the literary work on the institutional conditions of its production, dissemination and reception. The authors were not asked to follow a single method but were free to stress those aspects of the reception and dissemination process that seemed the most relevant in the context of the country or field they were focussing on. The result is a collection of articles that not only illuminates common ground and regional peculiarities of the reception process but also casts light on the multitude of possible approaches to the study of literary reception, especially in an intercultural context. Cumulatively they aim to contribute to an understanding of the workings of the "European intellectual space $^{\prime 4}$ and the mechanics of the movement of major works of fiction within that space, throwing light on the common impact of the novel and local variations in part conditioned by structural differences between the individual literary fields.

\section{Transfer and Reception}

The basic assumption underlying this collection of articles is that a book only becomes culturally relevant through being read, and the contexts in which it is read can be very different. To analyse the movements involved, Bourdieu's concept of the field proves particularly useful, especially since it accommodates various forms of mobility. The position occupied by a work within its own field may vary over time and, placed in the field of a different literary culture, the work may again find itself occupying a different position. In Pascale Casanova's view the very fact of translation can be an act of consecration moving the book from its local origins to a wider readership. Recognition across national or language borders can help legitimise it as literature. Furthermore, the success of one translated work can reflect back on the literary field from which it comes and raise its status. ${ }^{5}$ After the rupture in German cultural life caused by the National Socialist dictatorship, World War II and the subsequent division of Germany, the post-war West German literary field had in practice slipped to the periphery of European literary life and needed a boost in status. Casanova's basic idea about the international circulation of literature as movement between periphery and centre thus has its uses to help understand the differing nuances in the reception of the same work in different parts of Europe. Her

4 Sapiro (2009).

5 Casanova (2004) 135. 
tendency to identify the centre too rigidly with Paris that "managed to sustain its position - at least until the 196os - as the centre of the system of literary time", ${ }^{6}$ however undermines the analytical potential that her basic ideas with their distinction between more and less autonomous literary fields has to offer. Her book has justly met much criticism for its francocentric view. ${ }^{7}$ However in the case of Die Blechtrommel, which was incidentally written by Grass while living in Paris, it seems that the initial success of the French translation may have contributed to its international reputation. ${ }^{8}$

Given sufficient distribution and critical acclaim, the work becomes part of what is rather problematically termed "World Literature". The expression, famously coined by Goethe, is only practically useful if it is not understood simply as the aggregate of all the literatures of the world, but rather in the sense that Damrosch uses the term as a "mode of circulation and reading." Individual works, then, only form a meaningful part of "World Literature" as long as they are read and discussed. In the following various issues and approaches to the study of reception will be more closely examined.

\section{Reception Studies and Its Origins in Reception Aesthetics}

At first sight, it might look as if researching the reception of literary works has had its finest hour a few decades ago. The most important theorists of Reception Aesthetics, the German scholars Wolfgang Iser (1926-2007) and Hans Robert Jauß (1921-1997), published their main works in the 1960s and 1970s, and their ideas entered European literary theory in the course of the 1980 . But after that they seemed to have disappeared totally; that is, in their most strict, original form. In practice there remains much literary research that we still could classify as 'reception' -research. To make that more specific it is important, in the first place, to define reception in a broader sense than was done by the theorists of reception aesthetics of the first generation. Reception in our understanding is not limited to the way concrete (amateur) readers reacted to a certain literary text, but it includes all sorts of readers, including historical and professional readers. For instance the private notes in the diary of a contemporary of Goethe in which he writes down his first impression of a newly published work of the master, as well as a review on Facebook of a newly published poem in 2015 are

6 Casanova (2004), 89.

7 See D'haen (2012) 104-111.

8 See the contributions of Stéphanie Vanasten and Rebecca Braun in the present book.

9 Damrosch (2003) 5 . 
both documents that can be studied in reception studies - as is everything in between, like the letters from a writer to his publisher or the correspondence with an editor or translator, and, of course, all sorts of traditional forms of reviewing in dailies and weeklies. Many of the documents mentioned above are only made public after the event, where they can help to reconstruct the reception history of a certain literary work, oeuvre or author.

The spiritual father of Reception Studies is generally considered to be the German literary scholar Hans Robert Jauß, who was a professor at the University of Konstanz from 1967, and who was the founder of the so-called Konstanzer Schule. Jauß's inaugural address, entitled "Literaturgeschichte als Provokation der Literaturwissenschaft" rapidly became famous and has come to be regarded as the manifesto of reception aesthetics. Jauß rejects structuralism, which considered the literary work as an autonomous, timeless and unchanging object that purely existed on its own. He, instead, sees the dynamic relationship between permanently changing groups of new readers and a literary work, as crucial in the life of the work.

Das literarische Werk ist kein für sich bestehendes Objekt, das jedem Betrachter zu jeder Zeit den gleichen Anblick darbietet. Es ist kein Monument, das monologisch sein zeitloses Wesen offenbart. ${ }^{10}$

The literary work is not an object, that reveals timeless and transcendental values in itself, but status as literature is attributed to texts by the readers. In itself a text does not exist - literary or not - it only exists as living literature as far as readers assign value to it. Jauß makes a distinction between the text as 'fact' (Tatsache) and as an 'event' (Ereignis).

The manuscript that Günter Grass wrote in Paris, at the end of the fifties, and that he provided with the title Die Blechtrommel, the first chapter that he read aloud to the small audience of the Gruppe 47 at the end of 1958, and - in a sense - even the printed book that his publisher brought on the market in 1959 under that title, are all facts. The book became an event by virtue of everything that happened around the text: from the author's being granted the Preis der Gruppe 47 for the first chapter and the fact that a publisher was willing to publish it, through the opinions of the reviewers on the novel, to the way in which literary historians, analysts and translators contributed to the world wide reputation of the book. The essence of reception research lies in the understanding that no text has value in itself, but that literary value is always assigned by the various actors in the literary field.

10 Jauß (1970) 171-172. 
Looking back on more than four decades of reception aesthetics in 2011, the Swiss literary scholar Fabien Pillet listed several points of critique. It has, for example, been stated that the focus of reception studies was too much on classical Western European literature, and that there is a wide gap between the theoretical and practical concepts of the approach. Pillet also deals with the strong theoretical critique of the ideas of Jauß and Iser by the prominent French literature sociologist Pierre Bourdieu.

Both reception studies and Bourdieu's sociological insights share the above mentioned fundamental view that literary value is attributed to a text. Bourdieu, however, considers reception aesthetics to be still too essentialist. One of his main objections is that reception studies take the literary text too much for granted, for given as objective fact, without taking into consideration the role of the institutions that make the text into a literary text. Reception aesthetics believed, wrongly in Bourdieu's opinion, in a pure reading of texts themselves disregarding any historical ties they might have, particularly with regard to their production..$^{11}$ Reception research, according to Bourdieu, also does not take into account the (unconscious) prejudice, motivated by his prise de position, of the researcher:

le lecteur dont parle reéllement l'analyse (...) n'est autre que le théoricien lui-même qui, suivant en cela une inclination très commune chez le lector, prend pour objet sa propre expérience, non analysée sociologiquement, de lecteur cultivé."12

Despite the above mentioned reservations shared with Bourdieu, Pillet emphasises the usefulness of reception studies and he is still convinced of its future.

Notre étude a ainsi mis en évidence les tensions internes et les facteurs externes qui montrent qu'elle ne peut plus se pratiquer comme elle le fut dans les années soixante-dix et au début des années quatre-vingt. Malgré cela (...), nous avons vu que de nombreux concepts forgés par les auteurs de l'École de Constance (...) demeurent actuels dans la mesure où ils sont repris par les plus importantes théories critiques contemporaines comme la sociologie littéraire et le cognitivisme. Cela illustre la pertinence et la capacité d'adaptation de ces théories ou, si l'on préfère,

$11 \quad$ Pillet (2011) 766.

$12 \quad$ Bourdieu (1998) 491. 
la compatibilité entre l'École de Constance et des approches plus directement contemporaines. ${ }^{13}$

Further evidence that research of reception is still alive and doing well are the hundreds of references to books and articles in online-databases like MLA or the Dutch BNTL (the Bibliography on Dutch Literary Studies and Linguistics). At the same time one can see that 'reception' has become a far broader concept than it was in the early days. It has become more current to describe the process of the public reception of a novel or a collection of literary works, both in an international context - 'In what way are Joseph Roth's or Charles Dickens's novels received by critics and reviewers abroad?' 'What role did publishers or translators play?' - or national - 'In what way is a certain literary work received by anthologists, writers of school books or, particularly, book reviewers?'

\section{Book Reviewing as a Specific Form of Reception}

In the early practice of reception studies the role of book reviewers or critics was remarkably absent, which is quite strange, because book reviews are probably the most visible form of reception for both the contemporary reading audience and professional readers like literary scholars. The reviewer is usually the first to publicly give his or her opinion and insights on a recently published literary work and can often be regarded as the first institutional actor in the process of establishing a novel's career in literary history and the canon.

In analysing book reviewing two 'schools' can be discerned. On the one hand there is the research that focused on the argumentation in literary reviews. Here the review is considered an autonomous text and the main goal of the researcher is to analyse the type and amount of evaluating aspects in a review, but surely other aspects apart from valuation must be taken into account. On the other hand there is the institutional analysis, based on Bourdieu, that sees the role of the critic as a function in the whole of the institutional process of literary life.

Both schools have their evident limitations. For an analysis of argumentation in book reviews - which was the dominant approach for a long time - one only had to read the reviews; any knowledge of the discussed book, writer or oeuvre were in fact considered irrelevant. It must be stated that it is quite remarkable to approach literary criticism autonomously. Of course, it is in the nature of the genre that it always refers to other literary works, and to the world

13 Pillet (2011) 781. 
view and reality of the author. And the review itself aims to communicate, be it with the newspaper reader, a competing reviewer or the author of the book. This 'target in-itself'-character of the method contributed to its failure, but it was in fact an inevitable consequence of the autonomous approach from the beginning.

The opposite objection can be raised against the institutional approach, as it was for instance operationalised by, among others, C.J. van Rees in his important and now classic article on the mode of reception of the poetry of the renowned Dutch poet Hans Faverey. ${ }^{14}$ Van Rees conducted undoubtedly pioneering work within Dutch literary studies. He was the first to have thought through the consequences of the assumption that literary value is not an objective and autonomous fact, but the result of a process of assignment. On the other hand it can be argued that even Van Rees's institutional approach is, in fact, still too static. He takes too few parameters into account, such as changes in the literary field during the period studied, and ignores the uniqueness of each review and reviewer.

So we see that both these approaches are in their own way reductionist: the first by considering reviews as autonomous objects, the other by not taking into account the unique character of the literary text and the reviewer, that is at stake. One way out of this dilemma can be found in a book published in 1996, by the German literary scholars Renate von Heydebrand and Simone Winko: Einführung in die Wertung von Literatur. The importance of their book lies in the essentially rather obvious assumption that literary critics have a function in a literary process and therefore can not be understood as static institutions. In a sense, von Heydebrand and Winko reconcile the institutional approach with a text-oriented approach. They choose an institutional perspective, with their basic assumption that literature is a Sozialsystem in which objects do not possess objectively demonstrable intrinsic value, but in which their value is awarded. Their crucial assumption is to see the practice of both reviewer and reviews as a process that arises from the interaction of three variables: the axiologische Werte (axiological values), the attributive Werte (attributive values) and Zuordnungsvoraussetzungen (categorical assumptions).

The 'axiological value' is defined by Von Heydebrand and Winko as the measure by which an object or one of its features can be seen as having value. It can also be used to justify further, derivative, values. ${ }^{15}$ The process of attributing value is done by the reviewer (or any other reader, of course).

\footnotetext{
14 Van Rees (1987).

15 Von Heydebrand/Winko (1996) 40.
} 
Axiological values become concrete in relation to an object only when applied as attributive Werte (attributive values). ${ }^{16}$ So the essence of this view is that value is not an objective intrinsic factor, but is always attributed from the outside. Axiological values are generally applicable. Attributive values, however, always refer to a particular, concrete object. To make the step from the one to the other von Heydebrand and Winko introduce a third phenomenon, the so called Zuordnungsvoraussetzungen (categorical assumptions) of the subject. These are the conditions which need to be met in order for the evaluator to apply (attribute) the axiological value to the object. These can be subjective experiences as well as individual and collective knowledge on the part of the evaluator. ${ }^{17}$

In summary, the reviewer or critic has Zuordnungsvoraussetzungen based on his or her set of values and thus a repertoire of generally applicable value judgments that can result in assigning value properties to an object. The interplay between the attributive and axiological values makes it possible to explain the varying and sometimes contradictory ways in which an identical literary object can be judged by various critics.

\section{Imports and Translations in the Literary Field}

The reception of imported and translated works raises specific issues resulting from their transit from one social and cultural environment to another. Comparative reception research may on the one hand contribute to an understanding of a work's potential for generating different readings, and on the other hand reveal differences in the working of the fields. The international success of a book like Die Blechtrommel is evidence that the interpretative potential of a work does not restrict it to a single field or context. It may well be, however, that its success has different causes at different times and in different places. This is why studying how a work is understood, or in some cases misunderstood, in different environments is important.

In the case of translations the problems start with the language itself, since no translation can carry exactly the same connotations as the original text. The presence of the translator, usually deliberately underplayed in the marketing of the translation, intrudes on the text, which remains of necessity an approximation, a compromise, which the translator has to make to the best of his or her judgement. The work of the translator is coloured not only by his or her

\footnotetext{
$16 \quad$ Von Heydebrand/Winko (1996) 42.

17 Von Heydebrand/Winko (1996) 44.
} 
interpretation of the original text, but also by his or her understanding of the cultural context of the book's inception. Translation in the narrower sense is only part of the problem. The book moves not only from one language to another, but also from one literary field to another, in which the readers' expectations may differ noticeably from those of the readership that the author may have been consciously addressing. The translator, as intermediary between the work and its projected target audience, needs to be inherently aware of the of the expectations and limitations of that audience and therefore constantly has to negotiate between what she understands as the meaning of the text and what would be accessible to her readers. Even within the same country and the same language, the transition from one publishing house to another with a different image and different marketing or branding policy may strongly influence the way the book is received. Even the reissue of a hardcover book as a paperback can have the effect of changing its value in terms of symbolic capital. This problem is enhanced in the case of international transfer. Not only can important features get "lost in translation" but they can also get lost in dissemination if the book ends up with the wrong publisher. And though the literary fields in most advanced European countries may be fundamentally similar in many respects, they are never exactly equivalent. As Pierre Bourdieu points out in an essay of 2002, it makes a difference whether it says Suhrkamp or Seuil on the cover of a book. With imported literature the channel through which the book has been discovered and promoted needs to be taken into account. ${ }^{18}$

Bourdieu's article is a plea for research into the social and institutional conditions of the intercultural reception of ideas, which, he claims contrary to common belief, are very much bound up in their own nationalisms. Bourdieu takes as an example the controversy between Habermas and Foucault, which he considers to be not entirely explicable simply in terms of differences between the ideas themselves, but rather through differences in the contexts in which the ideas were formulated. On the one hand the whole vocabulary of the disciplines concerned carries very different connotations in languages and scientific traditions as different as those of France and Germany. On the other hand there is always tension between the ideas of one thinker and the discursive context in which they were formulated. This tension, which is actually responsible for the novelty of the ideas expressed and is thus essential to their understanding, gets distorted in the transition from one environment to another. French intellectual flirtation with Heidegger, to cite another of Bourdieu's examples, is best explained, not so much by a yearning for German 
irrationalism as for domestic reasons, in the desire to counter the predominance of Sartrean existentialism. ${ }^{19}$

With his examples taken from translations of anthropological and sociological theory Bourdieu makes his point very clearly, but similar processes of appropriation can be observed in the import of literary works. Interest in Die Blechtrommel was not due to its just being a new German novel among others, but rather because it made new departures from the expectations of the German readership. Its avant-garde character aroused interest. This is in accordance with the ideas of Jauß and his school with regard to aesthetic progress. Literary history is made by the works that breach old expectations and contribute to the evolution of new horizons. ${ }^{20}$ It is not unusual for works to enter the canon after originally having provoked moral and aesthetic outrage. They remain in the canon as long as they continue to stimulate discussion. ${ }^{21}$ It is no surprise that readers' expectations may differ across national and language borders, but if we can apply Bourdieu's aforementioned observations to fiction, then we might expect to find that different readerships of a work might locate its novelty in different features. In Die Blechtrommel the novelty may be seen to lie in the grotesque character of many episodes, the ambiguous depiction of petit bourgeois morality, in the unexpected narrative perspective - after all the narrator's type of unreliability stands in a category of its own - or in quite specific individual issues which may have little to do with the book itself. Evidence from the essays in this book shows that the focus of the critical reception of the novel is quite variable. It can be on the avant-garde nature of the work (Italy), on its "Germanness" (UK) or on locality (Poland). When translated and introduced to a different field, the same work, in so far as it still is the same work, confronts a different set of expectations which it breaches in different ways.

Comparing the international reception of Die Blechtrommel with its original reception in Germany and comparing its reception as a foreign, or explicitly German novel, in different countries has broader implications for understanding how neighbouring literary fields work and how they interact. At issue here are the evaluation criteria applied both in domestic reception and in the international context. The essays collected here suggest that the weight given by international reviewers to intrinsic aesthetic considerations seems often to be greater than that attributed by the domestic reviewers, who appear to be more concerned with extra-literary issues.

\footnotetext{
19 Bourdieu (2002) 5 .

$20 \quad \operatorname{Jauß~(1970)~} 177$.

21 Cf. Parry (2015) 100-101.
} 
Grass himself claims to have been rather surprised by the international impact of his novel. In his author's introduction to the second English translation of Die Blechtrommel, by Breon Mitchell, Grass reminisces on his original reaction to the very first suggestion in 1959 that the novel might be translated into English. Asked by the émigré American publisher Kurt Wolff whether he thought the American reader would understand the novel, Grass replied: "I don't think so [...] The setting is provincial, not even Danzig itself, but a suburb. The novel is filled with German dialect. And it concentrates solely on the provinces" ${ }^{22}$ If Grass's original modest assessment of the novel had been accurate, which it was if we look only at the setting, the success of this particular work might indeed seem counterintuitive. Kurt Wolff's response to Grass's qualms, that "all great literature is rooted in the provincial" is hardly a convincing explanation, since so much literature that is rooted in the provincial fails to transcend its roots, translates badly and hardly spreads beyond national borders. Quite obviously Grass's novel does transcend its roots and brings the provincial milieu to life by the richness of the narrative. But maybe this is partly because the Danzig of Grass's youth is a thing of the past and is now as remote from his German readership as it is from readers elsewhere. So, in fact, Grass creates his own Danzig of the mind, which is then equally accessible to readers anywhere. The only exception might be other displaced Danzigers and it is significant that one of the most damning condemnations quoted by Veronika Schuchter in this book, appeared in Unser Danzig a journal of the 'Heimatvertriebenen', an organisation representing Germans expelled from Danzig at the end of the war. This was a lobby with specific interests, which were clearly not advanced by Grass's novel. While that review appreciated the accuracy of Grass's description of the place it strongly objected to what it saw as a completely depraved representation of the people. ${ }^{23}$

The specificity of time and place is not necessarily a hindrance to the international reception of a work of literature. If the author succeeds in (re)constructing the milieu without making too many demands on the advance knowledge of the readers, a good novel should be accessible to any readers. This is the case with Dostoevsky's St Petersburg, Joyce's Dublin and Günter Grass's Danzig. The same demand applies to expectations regarding the morals, beliefs, gender relations etc. But not every book is equally accessible to every community at all times. This is why David Damrosch maintains that in

\footnotetext{
22 Grass (2010) vii.

23 Loschütz (1968) 25-26.
} 
the course of time works can enter into the realm of "World Literature" or fall out of it again - a process that can occur with the same work more than once. ${ }^{24}$

The canonised status of the work unavoidably has the effect of distorting the way later generations receive it. The book or a secondary product, the film or a translation, form the material of the reception together with the reputation accompanying both book and author. The reception history of Die Blechtrommel is in the first instance the history of readings of one book, and the criteria applied in the reviews are interesting in themselves. But in a case as controversial as the novel originally was, the whole reception process must also be seen in terms of a cultural event. The controversy surrounding the original publication has over time snowballed into a myth of scandal and for the outside reader, unacquainted with the context of West German writing at that time, the scandalous reputation of the novel will have acted as an enticement.

A further peculiarity of imported literature is that a book's reputation or that of its author may rise quite independently from the work's dissemination - or at least from the dissemination of the translation. Even in contexts like The Netherlands where, as Jos Joosten shows in this volume, the translated novel itself only received meagre attention from reviewers, the name of Günter Grass soon came to be indelibly associated with Die Blechtrommel and its protagonist Oskar Matzerath. This shows how the reputation of a work can outpace that of its author, whose later work and activities in public life are continually measured by reference to his early novel. This is the case of Günter Grass in Germany itself, and internationally, where his political activities are less well known, this effect is even more conspicuous.

The reception of Die Blechtrommel thus provides a test case for studying canonisation processes on a national and international level. It reveals subtle differences in the way the literary field is constituted in various countries, and it can contribute to considerations of whether there is such a thing as a European literary space. The reception of Die Blechtrommel is of genuine heuristic value also because the life span of the novel already covers half a century and it continues to be in print in many languages. Indeed with the coordinated project of retranslation on the occasion of the fiftieth anniversary of its first publication, the novel reached the zenith of its consecration within the lifetime of its author - a feature unusual even for classics. The retranslations were motivated by the double consideration to do justice to the author's intentions and to address the new readership of the 21st century. In the first respect the translators had the support of the author himself, through his cooperation in 
translation workshops - albeit a support not entirely unprejudiced by the bias of a famous author looking back in retrospect at the work of his youth.

\section{Structure of the Present Book}

Many studies on the international impact of Günter Grass and his work exist, notably the essay collection edited by Rebecca Braun and Frank Brunssen Changing the Nation which gives a very broad overview of both the international dimension within Grass's own literary work and his public standing in various countries. The focus of the present collection is different in that it concentrates on the progress of one novel, Die Blechtrommel, towards its current international canonical status. We take a look in the cradle of Gunter Grass's role as an author, the starting point of his literary career and its path throughout Europe. The articles deal with the book's publication history, its treatment in reviews and its effect on the subsequent reception of its author. The articles in the present book, written while Grass was still alive and very active, register the impact of Die Blechtrommel in different parts of Europe under differing conditions, and where the degree of familiarity with the German literary and political scenes varies quite considerably. They throw light on the differing positions that the same work can occupy on the domestic literary field and in an international context. Inevitably they also touch on the issue of authorship, in that they reveal a common tendency for the author and the figure of Oskar to be conflated. This is the case in Germany where Grass was more than once featured on the cover of the influential newsweekly Der Spiegel with a tin drum. In part Grass derived the authority for his political engagement during the election campaigns of the 1960 from the anarchic Oskar and the publicity accorded the novel and the central character continued to overshadow both the critical reception of Grass's later works and his public interventions. The constant subliminal presence of the early novel was not always conducive to a balanced discussion of Grass's general role in public discourse. This phenomenon is apparent in varying degrees in other parts of Europe. Comparison of Grass's reception in different parts of Europe reflects differing attitudes towards the role of the public intellectual. and, looked at over a period of more than half a century it shows that attitudes change between generations. And if some of the German obituaries seem slightly more reticent in their appraisals than the eulogies in the international press, this reveals growing irritation at the way writers of Grass's generation presumed moral authority in general. ${ }^{25}$

25 See e.g. Böttiger (2015). 
These positions are, however, not static. The international reception of Die Blechtrommel exemplifies the way the original context of the work can gradually recede as its place in the canon becomes established.

The articles in this book more or less trace a chronological and geographical trajectory through Europe. Starting with Germany, as the country of origin of the book, and then moving to Poland, to which the novel's principal location now belongs, we end in Sweden where Grass's received his ultimate literary recognition when he was granted the Nobel Prize. The collection begins with Stefan Neuhaus's contribution which clarifies some major theoretical positions underlying reception research, evaluation practice and the canonisation process from the point of view of Reception Studies and of Bourdieu's culturalsociological approach. Basing his argument on von Heydebrand and Winko's distinction between autonomous and heteronomous categories in literary valuation, where the self-referentiality of the former is conducive to advances in aesthetic practice whereas the latter categories tend to be applied by media criticism and the broader readership, he plots the passage of Die Blechtrommel in Germany from the controversy of its initial reception to its acceptance as part of the established canon.

The (West) German reception of the novel is more extensively examined in Veronika Schuchter's essay which distinguishes various phases in the reception process. After the initial controversial reception of the novel in the early $1960 \mathrm{~s}$ interest in the novel revived with the release of Volker Schlöndorff's film adaptation in 1979 and once more with the award of the Nobel prize twenty years later. For some time after the release of the film the influence of Schlöndorff's interpretation was visible for example in the selection of which episodes were foregrounded in discussion of the book. Schuchter finally emphasises the growing discrepancy between the uncritical appreciation of the novel and increasing irritation with Günter Grass's interventions in the political sphere.

The other European country in which Die Blechtrommel is so to speak "at home" is Poland. In his historical account Mirosław Ossowski shows that interest in the novel, which was debated in Poland well before an official translation became available, had much to do with the novel's specific setting in Danzig and its view of the German and Polish communities there in the inter-war years. Interestingly one official reason for deferring publication of a full translation that was given in Communist Poland was that the novel might ostensibly upset Catholic sensibilities.

Similar arguments delayed publication of the novel in Italy. Eva Banchelli provides a strong insight into the Italian publishing business in the early $1960 s$. The initial reluctance of publishers to produce the work and the mixed critical reception when the novel was published reflect domestic considerations in the 
Italian literary field. There the avant-garde nature of the work played a greater role than its national origins. The strong influence of the Church, on the one hand, and the aesthetic conservatism of the Left, on the other hand, dominated literary life in the 1950s. A general change only came about when the more courageous young publisher Feltrinelli became interested in experimental literature and started to promote the Avant-garde and took over the rights for Die Blechtrommel from the more conservative Bompiani.

Rebecca Braun focuses particularly on the issue of authorship and follows up the relationship between the roles of Grass as author of The Tin Drum and as a public figure exercising a right to intervene in political debate. Rather than make this distinction, British criticism has tended to elide the author with the figure of the drummer Oskar acting out in life the role of public nuisance that he invented for his fictional character. Contrasting the reception of Grass in the UK, which stressed his Germanness, with that in the United States where Grass was accepted as a "World Author", she notes the characteristic British reluctance to accept the figure of the public intellectual who engages with politics from outside the actual political establishment. This distinguishes the UK both from the European continent and the United States. Whereas criticism in the United States follows more closely the German model, accepting Grass's authority as a Nobel laureate to comment on international issues, in Britain Grass's activities are largely written off as eccentricity. Legitimised by the half-century old novel and with the excuse of his eccentricity he is pardoned for the errors of his later years, the long withheld revelation of his brief service in the Waffen-ss and his provocative Israel poem of 2014.

In Jos Joosten's article the reception of Grass's novel in The Netherlands is analysed. The initial reception of Die Blechtrommel turns out to be paradoxical. When the novel was published in German it was hardly reviewed in The Netherlands, but very soon after its publication the first press articles appeared on Grass as a German literary phenomenon. In the following years Grass's name appears regularly in the Dutch papers as the best-known representative of the young German literature, invariably in combination with the title of Die Blechtrommel. However very soon the title of the novel became no more than just a mention: a passing allusion. Probably because of the financial risk involved, it took five years before the Dutch translation of the novel, entitled De blikken trommel was published in late 1964 . The translated version of Die Blechtrommel was only mentioned in the small, specialist newspaper sections dedicated to recently published new books, with only a few lines that, again, hardly discussed the novel (or translation) itself, but primarily referred to its already evident international success. The translation(s) of Die Blechtrommel have been reprinted about thirty times, and it is estimated that several 
hundreds of thousands of copies of the translation have been sold. Through the decades Die Blechtrommel primarily kept on playing a role as a mention, with new impulses on the occasion of the release of the movie and the Nobel Prize. It never led to a serious debate on the content of the book or its social or political meaning.

Elke Brems's article focuses on the reception of Die Blechtrommel in Flanders, the Dutch-speaking part of Belgium. Brems uses Mona Baker's concept of 'narrative framing'. Five frames are found in Flemish reviews on Die Blechtrommel. The first one presents the book as canonical and emphasises its rapid acceptance as a literary classic. The second one discusses the socialpolitical message of Grass's novel. Then there is the frame that mainly draws attention to the novel as a formal experiment and focuses on the innovative character of the book. A further frame is formed by the treatment of the earlier reception of Die Blechtrommel as a topic in new reviews of the book. The final frame discussed is that where Grass is considered as a public figure who has been formed by his own novel.

France, according to Stéphanie Vanasten, was one of the countries most receptive to Die Blechtrommel. Unlike later works by Grass with their wealth of allusion to earlier German history less familiar to French readership, Die Blechtrommel was recognised from the outset as a novel with a long European pedigree in the picaresque tradition. This understanding was enhanced by the selection of the novel for many years as set reading in the national curriculum for the agrégation in Comparative Literature. This national peculiarity constitutes a unique form of institutionally sanctioned canonisation in the European context.

The last three articles turn to Northern Europe. Christoph Parry and Liisa Laukkanen examine the reception of the novel in Finland. On the basis of reviews in the major Finnish press Parry discusses the first wave of reception when the novel was seen as an innovative break with the more traditional realism prevalent on the Finnish book market of the time. Reviewers quickly situated the novel in the context of "World Literature" and suitable parallels were drawn, as in France, to the tradition of Rabelais and Cervantes, even though these are considerably less well known in Finland than in France. One remarkable feature of the Finnish reviews, considering the climate in Finnish cultural politics of the time, is that the novel, despite its quite provocative nature, was not drawn into the polemics which characterised critical reception of newer Finnish novels at that time.

Liisa Laukkanen focuses on the retranslation of the work in 2009 which received only passing attention in the press. The canonical status of the novel was evidently taken for granted by the publisher who emphasised the fact in 
the paratextual presentation of the product. The author cites evidence from internet blogs which reveal a brief revival of interest in the novel while not paying much attention to the fact of its retranslation. One notable feature of the small and peripheral Finnish book market is that while most of Grass's work has been translated into Finnish, it is also mostly out of print.

In Sweden, too, despite the fact that most of his novels have been translated, interest in Grass and in contemporary German literature as a whole is, as Edgar Platen emphasises, relatively sparse. Discussing the press coverage of the celebrations surrounding the award of the Nobel Prize, Platen notes the strong trivialising tendency that almost severs the author from his work. This evident lack of appreciation for the historical dimension of Grass and his major novel in Sweden can be traced back to the earliest Swedish contact with the novel. As Janina Gesche discovered in her dissertation comparing reception in Poland and Sweden, even the publisher's own reader failed to grasp the historical dimension of Die Blechtrommel. Platen sees a possible explanation for the relative lack of interest and indeed of understanding of Grass and of German post-war literature in general in the fact that Sweden, having had no direct experience of World War II, had no real 'post-war' itself.

Taken together the essays in this volume present a varied view of the reception process in different parts of Europe. This leads to a final short observation about the reception of Die Blechtrommel. Its combination of both worldwide literary acclaim and economic success at practically the same time is remarkable in view of Bourdieu's theory of the division of publishing houses between those catering for the 'short run' and those specialising in the 'long run':

There is on the one hand, a short production cycle, based on the concern to minimise risks by adjusting in advance to the identifiable demand and provided with marketing circuits and presentational devices (...) intended to ensure a rapid return of profit through rapid circulation of products with built-in obsolescence. On the other hand, there is a long production cycle, based on acceptance of the risk inherent in cultural investments $(. ..){ }^{26}$

From a commercial angle Die Blechtrommel has been a huge success. To mention a few examples: in this book Vanasten speaks of "eine Riesenauflage" in France; in Joosten's article the amount of "several hundreds of thousands of copies" of the Dutch translation is mentioned. In their book Braun and Brunssen write that when the "translation into English appeared in February 
1963, The Tin Drum became an instant bestseller in the United States." ${ }^{27}$ At the same time the literary value of Die Blechtrommel was never contested. It is true that in the early phase of reception much controversy surrounded the issue of the novel's moral acceptability. But while opinions varied between critics as to whether the novel was in good taste or not, its literary quality as a whole was seldom challenged. In fact the discovery of its picaresque pedigree helped to qualify the work as major literature even in the eyes of more sceptical critics. There is reason to believe that Die Blechtrommel is at least an exception to Bourdieu's assumption that the 'commercial pole' and 'cultural pole' usually mutually exclude each other. ${ }^{28}$

Interestingly the cultural consensus does not apply in the same way to Grass's later writing or to his role as a public figure. In fact the impression made by his belated confession of his brief war-time involvement in the Waffen-ss and his controversial stance on international issues varies considerably, ranging from intense disappointment, particularly in Germany itself, to almost total lack of interest in Sweden and Finland. While the career of the author is generally understood throughout Europe as originating in the sensational success of Die Blechtrommel, the later reputation of the novel itself has proved more consistent than that of its author.

\section{Bibliography}

Adorno, Th.W. „Kulturkritik und Gesellschaft“, in Gesammelte Schriften. Vol. 10.1. (Darmstadt 1998)[1949]), 11-30.

Böttiger, H., „Ein Funke der Moderne. Sich irren, sich engagieren, sich streiten: Günter Grass symbolisierte einen Schriftstellertyp, den viele jüngere Autoren heute ablehnen“, in DIE ZEIT Online April 13, 2015. <http://www.zeit.de/kultur/literatur/2015-04/ guenter-grass-gruppe-47-blechtrommel $>$.

Bourdieu, P., "The Production of Belief: Contribution to an Economy of Symbolic Goods," in The Field of Cultural Production (Cambridge 1993), 74-111.

Bourdieu, P., Les règles de l'art. Génèse et structure du champ littéraire (Paris, 1998).

Bourdieu P., "Les conditions sociales de la circulation internationale des idées," in Actes de la recherche en sciences sociales 145(2002), décembre, 3-8. Reprinted in Sapiro G. (ed.), L'espace intellectuel en Europe, 27-39.

Braun, R. and F. Brunssen (eds.), Changing the Nation. Günter Grass in International Perspective (Würzburg 2008).

$27 \quad$ Braun/Brunssen (2008) 11.

28 Bourdieu (1993) 97. 
Casanova, P., The World Republic of Letters (Cambridge MA/London, 2004)[1999].

D'haen, T., The Routledge Concise History of World Literature. Abingdon (2012).

Damrosch, D., What is World Literature? (Princeton, Oxford, 2003).

Gonçalves da Silva, H.: "Peeling the Onion by Günter Grass. From Survivor Memory to Postmemory, and the Issue of a Responsible European Culture of Memory," in Braun/ Brunssen (eds.): Changing the Nation, 156.

Grass, G., The Tin Drum translated by Breon Mittchell (London, 2010).

Heydebrand, R. v. and S. Winko, Einführung in die Wertung von Literatur. SystematikGeschichte-Legitimation (Paderborn, 1996).

Jauß, H., „Literaturgeschichte als Provokation de Literaturwissenschaft", in Literaturgeschichte als Provokation (Frankfurt am Main, 1970), 144-207.

Loschütz, G. (ed.), Von Buch zu Buch: Günter Grass in der Kritik (Neuwied/Berlin, 1968).

Packalén, S., "From the Third Reich to the Third Space. Paul Celan, Erich Fried and Peter Weiss" in A. Stephan (ed.), Exile and Otherness: New Approaches to the Experience of the Nazi Refugees (Frankfurt am Main 2005), 121-132.

Parry, C., "The Literary Canon and its Role in the Construction and Communication of Collective Identities," in Chakrabarti C. and T. Lehtonen (eds.), Perspectives on Culture, Values, and Justice (Newcastle upon Tyne 2015), 97-113.

Pillet, F., "Que reste-t-il de l'École de Constance?," in Études Germaniques, 66 (2011), 3, $763-781$.

Sapiro G. (ed.), L'espace intellectuel en Europe: De la formation des États-nations à la mondialisation $X_{X} X_{-}^{e} X X I^{e}$ siècle (Paris, 2009).

Van Rees, C., "How Reviewers Reach Consensus on the Value of Literary Works," in Poetics 16 (1987), 275-294. 